\title{
The Image of Pagan and Christian Rulers of the Grand Duchy of Lithuania from the Second Half of the 13th and First Half of the 14th Centuries in German Chronicles
}

\author{
Yanina Ryier / rier_iaa@msu.by \\ Магілёўскі дзяржаўны ўніверсітэт імя Аркадзя Куляшова (Mogilev State A. Kuleshov University), \\ Mogilev, BLR
}

\begin{abstract}
This article deals with the image of the first rulers of the Grand Duchy of Lithuania in German chronicles. The aim of the work is to reconstruct the image of Pagan and Christian rulers of the emerging state, marking out similarities and differences, and to characterize the legitimacy of their status as monarchs in the eyes of German chroniclers based on the religion of the Lithuanian dukes. The article mainly focuses on Mindaugas, Vytenis and Gediminas, the most powerful and dynamic figures from the initial period of the foundation of the Grand Duchy of Lithuania.
\end{abstract}

\section{Keywords}

Ruler; King; Christianity; Paganism; Image; Power; the Grand Duchy of Lithuania. 
Many historians today pay great attention to the issue of state formation, and although these processes have been thoroughly examined during the 20th century and the start of the 21st century in Western Europe, the development of states in Eastern Europe, including the lands of former Rus' and the Grand Duchy of Lithuania, still requires more thorough research.

One of the most important signs (or characteristics) of any state is the specific control mechanism which is often called "power." Therefore, it is one of the most important things a researcher has to investigate when studying the history of state formation in a region. The symbol of power is the ruler of a state. He has his own character traits and creates his own politics, which can vary widely. He can also follow a different religion, but he is a symbol of the state. He is the person the state is associated with during a specific period of time. That is why it is very important to analyse not only the separate events or data related to those lands, but to investigate the image of a ruler as a representative of the state and as a political opponent when discussing the written sources created in neighbouring lands.

In this regard, it should be highlighted that one of the main characteristics which influenced so much the mediaeval chroniclers, especially in the Teutonic Order, was the religion of a ruler. This was very clearly shown in the example of the first rulers of the Grand Duchy of Lithuania. In these cases, not only politics, military events or the diplomatic relations between two states influenced the image created of a ruler - a duke or king (we will discuss these titles later) - but also their religion and whether it was pagan or Christian.

Within this analysis of the image of rulers during the first stages of the foundation of the Grand Duchy of Lithuania, the author looks at data from German chronicles from the 13th and 14th centuries: "The Livonian Rhymed Chronicle", Chronicon terrae Prussiae by Peter of Dusburg, Chronicon Livoniae by Hermann of Wartberge and Chronica nova Prutenica by Wigand of Marburg. The main narrative drive was their description of the first rulers of the Grand Duchy of Lithuania from the middle of the 13th to the middle of the 14th centuries. They are considered to be the original narrative sources which present the era of the rulers' reign. The later sources can also be used to compare the images of the same ruler at different times in order to discover the reasons for such differences. For example, in this article the author thought it appropriate to use a rhymed source by the Livonian author Augustino Eucaedius, written in the 16th century to create a picturesque image of the first rulers of the Grand Duchy of Lithuania, as it does not confuse general ideas and the research data.

The aim of this article is to reconstruct the image of pagan and Christian rulers of the emerging Grand Duchy of Lithuania, highlighting similarities and differences, and to characterize the legitimacy of their status as monarchs in the eyes of German chroniclers based on the religion of the Lithuanian dukes.

The central focus will be on three rulers of the Grand Duchy of Lithuania - Mindaugas, Vytenis and Gediminas, as the most powerful and dynamic figures from the abovementioned period. 
The period of the middle of the 12th century and the start of the 13th was extremely complicated for Eastern European lands. It was an era of pronounced feudal division, constant wars and the weakness of the duchies. In the middle of the 13th century, we can speak of the creation of a new state formation - the Grand Duchy of Lithuania - and the first Lithuanian duke, Mindaugas.

Mindaugas was the first Lithuanian prince to be noticed by chroniclers. At first he was a duke and then became a king of the Grand Duchy of Lithuania. This fact was highlighted by German chroniclers in a positive way, as was the fact that Mindaugas had been baptized. In fact, his coronation and baptism along with his wife Marta (or Morta) were focal points for medieval chroniclers, who stressed this along with his aggressive military politics. However, he cannot be compared with the famous European leaders of that time, as he was mainly a military leader, a leader of a compact chiefdom, who fought enemies and tried to bring smaller territories under his control. It is important to point out that the first dukes of this state were not particularly powerful and used all of their resources to protect the territory and power they had. ${ }^{1}$

Nevertheless, even Mindaugas used different sources to legitimize his power, the most important being his personal authority and religion. He is considered to be the first duke who ruled the Grand Duchy of Lithuania.

We know little of his origins, early life or rise to power. In the chronicles he is mentioned in a 1219 treaty as an elder duke, and in 1236 as the leader of all Lithuanians, ${ }^{2}$ but the historical written sources mentioning Mindaugas are very scarce. Much of what is known about his reign is from the Livonian Rhymed Chronicle and the Hypatian Codex. Both of these chronicles were created by the enemies of Lithuania and thus have an anti-Lithuanian bias, particularly the Hypatian Codex. They are also incomplete: both of them lack dates and locations for even the most important events. His father is mentioned in the Livonian Rhymed Chronicle as a powerful duke, but is not named; later chronicles give his name as Ryngold. ${ }^{3}$

Mindaugas' path to the title of king of all Lithuania is not clear. Ruthenian chronicles mention that he murdered or expelled several other dukes, including his relatives. The historian S. C. Rowell described his rise to power as due to "the familiar processes of marriage, murder and military conquest." ${ }^{4}$ During the 1230s and 1240s, Mindaugas strengthened and established his power in various Baltic and Slavic lands.

From 1244 to 1246 the Livonian Rhymed chronicle calls Mindaugas Myndowe, hoestekonic, der Littouwen kunic rich, ${ }^{5}$ meaning that the lands had been consolidated to some extent by that time. After his coronation and baptism he is named as the "king."

1 RIER, Yakov: Ocherki stanovleniya srednevekovuh evropeyskih gosudarstv v kontekste obshcheistoricheskih processov: prirodnaya sreda i socialnoe razvitie. Mogilev 2016, pp. 345-347.

2 Полное собрание русских летописей T. II. Ипативеская летописъ. Moskva 19624, p. 134.

3 Livländische Reimchronik (= LR). Ed. Franz Pfeiffer. Stuttgart 1844, p. 51.

4 Rowell, Stephen Christopher: Lithuania ascending: a pagan empire within east-central Europe, 1295-1345. Cambridge 1994, p. 38.

5 LR, p. 67.

6 Ibidem, p. 94. 
Mindaugas was baptized in 1251 in order to acquire some lands in western Lithuania and to be acknowledged as a king by Pope Innocent IV. The pope welcomed a Christian Lithuania as a bulwark against Mongolonian threats; in turn, Mindaugas sought papal intervention in the ongoing Lithuanian conflicts with the Christian orders. The process of the coronation and the establishment of Christian institutions took two years. The duke and his wife Morta were crowned in the summer of 1253. Hermann of Wartberge described this event as huius tempore Mindowe rex Letwinorum et Marta uxor eius baptismum susceperunt et coronam regni in Lethovia a domino Innocentio papa IVto. ${ }^{7}$

Relative peace and stability prevailed for about eight years. Mindaugas used this opportunity to concentrate on expanding to the east and establishing and organizing state institutions. Lithuania's relationships with Western Europe and the Holy See were reinforced. However, opposition to his power continued. He was not a strong leader who was able to concentrate all the power in his hands. The Livonian Order used their alliance with Mindaugas to gain control over Samogitian lands. However, Mindaugas ended the peace with the Order and the gains he had expected from Christianization proved to be insignificant.

Mindaugas may have reverted to paganism afterwards. His motivation for conversion is often described by modern historians as merely strategic. The chroniclers wrote that Mindaugas continued to practice paganism, making sacrifices to his god and conducting pagan rites in public. The Lithuanian king was killed along with his two sons in 1263 by an alliance of Daumantas and Treniota, after which Lithuania fell into internal disorder. ${ }^{8}$

His image in the German chronicles of the 13th - 14th centuries is rather contradictory. On the one hand, he was the ruler of an enemy state, while on the other, he was baptized and negotiated an agreement with the pope. That is why medieval chroniclers tried to give him a positive image. The author of the Livonian Rhymed chronicle calls him der Littouwen kunic rich Mindowen ${ }^{9}$ or richen kunec Myndouwen, ${ }^{10}$ though mostly he is just called a king - kunic Mindowe. ${ }^{11}$

It is necessary to emphasize here that Western European sources, especially those that were created on the territory of the Teutonic Order, characterized the rulers of the Grand Duchy of Lithuania using Western European titles such as "king", in contrast to the "Grand Duke" found in eastern Slavic, and in particular, Belarusian and Lithuanian annals.

7 Hermanni de Wartberge Chronicon Livoniae. In: Scriptores rerum Prussicarum (= SRP) II. Ed. Ernst Strehlke. Leipzig 1863, p. 38.

8 RIMŠA, Edmundas: Ar Mindaugo majestotinis antspaudas? In: Lietuvos dailès muziejaus metraštis 6, 2005, pp. 39-43.

$9 \quad$ LR, p. 67.

10 Ibidem, p. 97.

11 Ibidem, p. 94. 
Another chronicler who focused a great deal of attention on Mindaugas was Peter of Dusburg. Describing the Lithuanian ruler as "a king", he outlined the main political features of his reign. ${ }^{12}$

It should be noted that many German historians over the following centuries relied on the work of Peter of Dusburg. For example, in Zerbst in 1592, Caspar Shütz published the multi-volume Historia Rerum Prussicarum, where he examined the history of Prussia until 1525, paying particular attention to its neighbouring lands and states. In addition to the work by Peter of Dusburg, the creator of the chronicle also referred to works by Jan Długosz and other German annals and diplomatic documents. The first mention of the Grand Duchy of Lithuania and Mindaugas dates back to 1247. It is very interesting that he was called a prince ("fürsten") until $1251,{ }^{13}$ but after his coronation and adoption of Christianity the chronicler calls him "the king" (König in Littaw), after which Lithuania became much more prominent. ${ }^{14}$

Another original narrative source which describes the pagan period of the Grand Duchy of Lithuania is Chronicon Livoniae, written by Hermann of Wartberge, a Westphalian priest and member of the Teutonic Order, in the second half of the 14th century. The first reference to Lithuania in this source relates specifically to the coronation of Mindaugas, which was described by the author as an important event that gave Lithuania a king. ${ }^{15}$ In addition, considerable attention was given to the topic of Christianization, which was undoubtedly due to the author's membership of the Order. The author repeatedly mentions "pagan" neighbours, the need to renounce pagan deities, in particular Perun, and instead turn to St Mary and Christianity. ${ }^{16}$

If we try to sum up the resources Mindaugas used for the legitimization of his power which were mentioned in German chronicles of the 13th and 14th centuries, and try to create his image as a ruler, it should be noted that we cannot yet speak of his power being used in international politics. The first ruler of the Grand Duchy of Lithuania had to focus all his efforts on protecting his position in society and also on protecting his lands against enemy attacks, and - in the best case scenario - to expand his territory.

As a strong ambiguous leader, Mindaugus reinforced his power through the use of force, a successful military strategy, but also by organizing the economy, while marriage was also a means of legitimizing his status. Nevertheless, although his power had a certain authority, it was not strong enough and he had to constantly manoeuvre between his enemies and allies. The most strategic way to strengthen his power was through his baptism and coronation from 1251 to 1253 , which allowed him to remain as ruler for more than ten years. Nevertheless, he was flexible even here and used religion in his interests. He saw that the new Christian religion was unpopular among the population

12 Petri de Dusburg ordinis Teutonici sacerdotis Chronicon Prussiae, in quo ordinis Teutonici origo, nec non res ab ejusdem ordinis magistris ab an. MCCXXVI. usque an. MCCCXXVI. Ed. Christoph Hartknoch. Francofurti Lipsiae 1679, p. 186.

13 Schüтz, Caspar: Historia Rerum Prussicarum. Zerbst 1592, p. 27.

14 Ibidem, p. 35.

15 Hermanni de Wartberge Chronicon Livoniae, p. 38-42.

16 Ibidem, p. 45. 
and the majority of the nobles, and so he continued to hold pagan rituals, thus finding support from both sides. Therefore, the spirituals matters of the first Lithuanian king were very dependent on his personal political interests.

Moreover, despite the fact that he was the legitimate ruler over a political entity, his power was not strong or established, which is demonstrated by the fact that his enemies conspired to murder him along with his sons in 1263. The struggle for power after his death also reveals the absence of a mature system of state administration and succession. It could be concluded that during this period supreme power was not recognized by a certain section of the elite, while the hierarchy itself had not been fully established either. However, for some time his Christianity remained very important for German chroniclers, who focused on his personality and tried to show him as a noble ruler of Lithuania.

To summarize this image, I would like to present a Latin rhymed work by the Livonian author Augustinus Eucaedius:

\author{
Dux Mondauus erat, quo non crudelior alter, \\ Nec feritate fuit, nec bello maior et armis, \\ Quem Litaui, quem Samogetae coluere feroces, \\ Et dominum agnouere suum. Dux ille potentum \\ Vna Lionum bellum cum gente gerebat \\ Assiduum, et late vastabat milite campos. ${ }^{17}$
}

A completely different situation is typical for the era of Vytenis' and Gediminas' reign, who remained pagans until their deaths. The chroniclers presented them as strong but cruel and insidious enemies who could be extremely dangerous for their neighbours. However, even between Vytenis and Gediminas there were great differences in the images created and in the attitude towards them as rulers.

At the beginning of the 14th century, during the reign of Vytenis and then Gediminas (1316-1341), we can see the active development of power and the mechanisms for its legitimization. During Vytenis' reign, the Grand Duchy of Lithuania was consolidated enough to make it possible to consider it a state. He ruled between approximately 1295 and 1316 and was a talented military leader and diplomat, who came to the attention of the German chroniclers of the time.

One of the earliest sources mentioning his name was "The Old Oliwa Chronicle."18 He was called rex Letwinorum nomine Vyten after a battle in 1310 when a large number of Christians were killed. ${ }^{19}$ He was depicted as a strong courageous enemy with royal power.

17 Eucaedius, Augustinus: Aulaeum Dunaidum, continens seriem ac successiones archiepiscoporum Rigensium in Livonia, scriptum ad reverendissimum ac illustrissimum principem ac dominum dominum Sigismundum Augustum, archiepiscopum Rigensem designatum, ducem Megapolensem, principem Vandalorum, comitem Suerinaeum, ac Stargatiorum dominum, etc. In: Scriptores rerum Livonicarum II. Riga - Leipzig 1853, p. 408.

18 Die ältere Chronik von Oliva. In: SRP V. Edd. Theodor Hirsch - Max Töppen - Ernst Strehlke. Leipzig 1874, pp. 591-624.

19 Ibidem, p. 606. 
This image was frequently chosen by the Lyvonian chronicler and was typical of many Latin descriptions of Vytenis. In Chronicon terrae Prussiae by Peter of Dusburg, Vytenis is the first Lithuanian leader whose politics were the focus of more thorough investigation. He called him Vithenus Rex Lethowinorum and compared the ruler to other European leaders. ${ }^{20}$ The first information we have about Vytenis dates back to 1291 when the Lithuanian king Pukuver sent a large army led by his son to the Polish lands. ${ }^{21}$ There is a very interesting description of military events from 1294 when Vytenis laid siege to the land of Lenchici and occupied the city. The Lithuanian soldiers killed about 400 people and captured even more. But the most important description is of Vytenis himself, who is portrayed as an unrepentant pagan who burns cathedrals and commits sacrilegious acts: Eodem anno Vithenus filius regis Lethowie cum octingentis viris intravit terram Polonie, et in die pentecostes, dum in ecclesia Lunczensi canonici et ministry altaris et alli clerici cum solempni ornatu essent in processione, irruit hostiliter in eos, et in ecclesia ccc hominess cristianos trucidavit, clericos et prelates, quos voluit, captives secum duxit, omnem ornatum, calices et alia vasa ecclesie ad illicitum usum pertrahebat in contemptum dei, ecclesiam cum sacramentis redegit in favillam, depopulataque terra circum adjacent factaque maxima strage in populo dei, tantam multitudinem deduxit captivam, quod cuilibet Lethowino in divisione cesserunt xx hominess cristiani. $^{22}$

Naturally, such a description was consistent with the orientation of the text compiled by a chronicler from the Teutonic Order, and it must be evaluated with caution. But it is obvious that Vytenis was a pagan ruler, though one who was recognized and respected by his neighbours and even by his enemies.

The chronicle devotes much space to the events that occurred between 1305 and 1311, during which the Crusaders repeatedly attacked Grodno, which Vytenis successfully repelled, as well as the retaliatory campaigns of the Grand Duke of Lithuania against the lands of Prussia. ${ }^{23}$ On 7 April 1311 a battle took place at Barten between Vytenis's army and the army of the Order, led by Heinrich von Plotzke. Despite the fact that the Lithuanians repelled the first attack, afterwards they could not restrain the enemy's greater forces and retreated. Noteworthy in this regard is the assessment of the event by Peter of Dusburg, who considered this to be the punishment of a pagan prince who had been so troublesome to the Christian knights. He also emphasized the fact that in this battle, as in previous ones, Vytenis plundered and destroyed many Christian churches and also took away many captives. ${ }^{24}$ In general, it is worth emphasizing that the antagonism between the Christian knights and the pagans of Lithuania is a characteristic feature of the chronicles created in the lands of the Teutonic Order.

20 Petri de Dusburg Chronicon terrae Prussiae. In: SRP I. Edd. Theodor Hirsch - Max Töppen - Ernst Strehlke. Leipzig 1861, p. 163.

21 Ibidem, p. 155.

22 Ibidem, p. 156.

23 Ibidem, p. 180.

24 Ibidem, p. 176. 
However, all the authors agree that, despite his paganism, Vytenis was a brave and strong enemy with a successful military strategy that resulted in many conquests. ${ }^{25}$

Hermann of Wartberge also examined the era of Vytenis' reign. Although he does not mention his name, he does refer to a rex Letwinorum when describing the military events of the time. ${ }^{26}$

One of the most important written sources which can help reconstruct an image of the pagan ruler Vytenis is Chronica nova Prutenica by Wigand of Marburg. There is a focus on the events of 1311 - a military expedition by Vytenis and Rusins to Prussia, which was followed by looting and devastation. Though he has a generally negative image, the author of the chronicle still calls him Wytan rex Lithwanorum and highlights his courage. ${ }^{27}$

Vytenis is, therefore, an object of significant interest for German chroniclers. He is one of the most powerful and bravest figures from the formative stage of the Grand Duchy of Lithuania. It is interesting that he is mentioned even more often than Gediminas in many German chronicles. His name is often connected with successful military strategy. Although the chroniclers describe him as a cruel and savage pagan ruler, they do not deny his political or military abilities, while they also acknowledge his royal status. The following rhymed lines by Augustine Eucaedio give a clear portrayal of his image:

At Vithines belli ductor, Lituanis Heros,

Multa putans, ciuesque animo miseratus amicos,

Brunonem merita multabat morte Magistrum $[\ldots]^{28}$

The most complicated figure in this period of the history of the Grand Duchy of Lithuania is Gediminas. He is considered to be the ruler who founded the great political entity of the state and expanded its territory. He is also one of the most significant figures of early Lithuanian history, as he founded Vilnius, the capital of Lithuania, and established a dynasty which can be traced to other European monarchies such as Poland or Hungary. As part of his legacy he gained the reputation for being a champion of paganism who successfully diverted attempts to Christianize his country through shrewd negotiations with the pope and other Christian rulers.

Gediminas was born around 1275. As the written sources from this era are scarce, there is little known about Gediminas' ancestry, early life and assumption of the title of Grand Duke in 1316, and these issues continue to be the subject of scholarly debate. Various theories have claimed that Gediminas was either the son of his predecessor, Vytenis, his brother, his cousin, or his stableman. ${ }^{29}$ Notwithstanding, he managed to

25 Ibidem, p. 181.

26 Hermanni de Wartberge Chronicon Livoniae, p. 56.

27 Wigand von Marburg, Nowa kronika pruska. Edd. Sławomir Zonenberg - Krzystof Kwiatkowski. Toruń 2017, p. 128.

28 Eucadius, A.: Aulaeum Dunadium, p. 409.

29 Rowell, S. C.: Pagans, peace and the Pope. 1322-1324: Lithuania in the Centre of European Diplomacy. Archivum Historiae Pontificae 28, 1990, pp. 67-69. 
establish a dynasty which made Lithuania both secure and powerful. For this purpose he entered into direct diplomatic negotiations with the Holy See and wrote to Pope John XXII, promising to be baptized. However, he died as a pagan reigning over semi-pagan lands. Therefore, the letters sent to the pope were a wise diplomatic manoeuvre in order to protect his lands and strengthen his power. His internal administration also shows all the signs of a wise ruler. He protected the Catholic as well as the Orthodox clergy, raised the Lithuanian army to the highest level of efficiency then attainable, defended his borders and built numerous castles in towns such as Vilnius. Gediminas died in 1341, presumably killed during an attempt to overthrow him. He was the founder of a new Lithuanian dynasty - the Gediminids - and laid the foundations for the state's expansion and is sometimes referred to as the "true" state founder.

In his decrees and diplomatic documents he was called rex Litvinorum Rutnenorumque or rex Litvinorum et multorum Rutenoram, which meant that he had strength and authority in both his native lands as well as in neighbouring ones. ${ }^{30}$ The personal authority of the ruler was supported by historical tradition and the norms for creating laws, so it was at this period that we can see a strong powerful authority, which was the symbol of society. Therefore, by the end of the 14th century, a central administration had been formed and the traditional mechanisms for legitimizing power had been established and put into practice.

Unfortunately, there are very few narrative sources which describe Gediminas or his politics. For example, “The Old Oliwa Chronicle”, which portrays Vytenis as a powerful enemy of the Order, does not mention Gediminas or the period of his reign, but continues with a description of Lithuanian politics from 1345 and 1347, mentioning Olgerdus and his brother Kynstut (rex Litwinorum ${ }^{31}$ and Kynstot ${ }^{32}$ ).

Nevertheless, a number of German chronicles still refered to Gediminas as the king of the Grand Duchy of Lithuania. In Chronicon terrae Prussiae Peter of Dusburg calls him Gedeminum Regem Lethowinorum ${ }^{33}$ and briefly describes the first milestones of his reign. In particular, he emphasizes Gediminas's wish to adopt Christianity, as well as his alliance with the Polish king, achieved through the marriage Władysław Łokietek's son to his daughter. In addition, the alliance of the Lithuanian ruler with Riga stands out, aimed at weakening the Teutonic Order. ${ }^{34}$ The difference in the attitude of Peter of Dusburg towards Gediminas before and after his proposed baptism is revealing. At first, he wrote that hoc facto legati solempnes nuncios miserunt ad Gediminum regem Lethowinorum, ut negocium sibi commissum a sede apostolic illi proponerent, et diligenter investigarent, si ipse cum populo regni sui vellet baptismi graciam suscipere, et relicta ydololatria nomen domini nostri Jesu Cristi humiliter adorare. ${ }^{35}$ So here we see a quite neutral statement, acknowledging both

30 Chartularium Lithuaniae res gestas magni ducis Gedeminne illustrans = Gedimino laiškai. Ed. Stephan Christopher Rowell. Vilnius 2003.

31 Die ältere Chronik von Oliva, p. 606.

32 Ibidem, p. 617.

33 Petri de Dusburg Chronicon terrae Prussiae, p. 191.

34 Ibidem, p. 193.

35 Ibidem, p. 191. 
the royal status of Gediminas as well as his recognition as a ruler by European states. But he refused to and came to Masovian lands, which was why his image became very picturesque and overly emotional: Firmata igitur pace, dum fratres et alii cristifideles terre Lyvonie et Prussie et aliarum parcium vicinarum indubitanter crederent, quod non deberent a modo prelia exerceri, et jam disponerent gladios suos conflare in vomeres, et lanceas in falces, idem prophanus fidei hostis et fidelium, tanquam aspis surda, obturavit aures suas ad salutaria monita domini pape, per dictos nuncios eidem cum omni diligencia proposita, quia dum de salute sua et suorum cogitare debuerat, quomodo scilicet posset digne et cum reverencia debita suscipere baptismatis sacramentum, ipse sequens vestigia predecessorum suorum, totum conatum suum in destructionem fidei et fidelium convertit. ${ }^{36}$ One can see that the second note is quite different to the first one in tone. Whereas the first note portrays a pagan ruler with whom it was possible to have diplomatic relations, the second one presents a cruel traitor and a military chief who commits crimes against Christians.

An important narrative source is the work by Wigand of Marburg. The author, describing events from the end of the 13th century to 1394, was apparently not familiar with the work of Peter of Dusburg, but he actively used the information from "The Old Oliwa Chronicle" and the work by Hermann of Wartberge. Describing the events related to the history of Lithuania during the reign of Gediminas, the chronicler names the latter regis paganis and rex, emphasizing his desire to pursue a policy aimed at combating the Order. The chronicler reports: Anno 1331 sequenti anno in die nativitatis Marie Virginis rex Lokut Polonie concepit malum propositum vindicate cum auxilio Gedemyni, regis Lithwanorum, qui sibi condixerant, se pretacta die paratos esse. Tandem rex Gedemyn in potenti manu intrat cum paganis terram Osterrodensem et igne vastat eam $[\ldots] .{ }^{37}$

It should be noted that the author of the chronicle, who mentions Gediminas along with other European rulers and did not deny his rule or the power that he possessed in society, deprives him of the title of "king", probably in order to emphasize his lower legitimate status: Tres reges erant hostes ordinis, Lokut rex Polonie, Gedemyn Lithwanie paganus et rex Ungariae. ${ }^{38}$ However, when describing the events directly related to his politics, the title "king" is present. Nevertheless, there is very little information about him and the few references to Gediminas are more likely to have been the result of guesswork.

Therefore, the chronicles which were created on the territory of the Teutonic Order firstly portrayed Vytenis as a powerful ruler and military aggressor. The figure of Gediminas is either mentioned briefly or not at all. This is possibly connected to the issue of the legitimacy of his rule, which was extremely important for European diplomats and chroniclers of that time.

Despite the different attitudes towards Gediminas's character and his legitimate right to sit on the princely throne, in all the narrative traditions - not just German, but also Polish, Belarusian and Lithuanian - it is not disputed that the ruler pursued a successful policy aimed at institutionalizing his power in the development of statehood. One such

36 Ibidem, p. 191.

37 Wigand von Marburg, Nowa kronika pruska, p. 150.

38 Ibidem, p. 156. 
mechanism for legitimizing power and later for strengthening the Gediminids dynasty, was his clever marriage policy. As was mentioned above, the ruler of the Grand Duchy of Lithuania was in an alliance with the Polish king through the marriage of Władysław Łokietek's son to his daughter. This fact was described by Hermann of Wartberge as well as by Peter of Dusburg. The chronicle contains the notes that Anno domini MCCCXXVI Loteko rex Polonie rogavit Gedeminum regem Lethowinorum, cujus filiam filius ejus noviter duxerat in uxorem, ut ei aliquos armigeros de gente sua mitteret. Qui precibus ejus acquiescens, MCC equites destinavit ei. Hii de mandato dicti Lotekonis adjuncti populo suo armata manu hostiliter intraverunt terram marchionis de Brandenburgk circa civitatem Frankenvurdam, et totam illam contractam, que continebat ultra centum et XL villas, ecclesias parochiales totidem, cenobia monachorum ordinis Cisterciensis tria et claustra sanctimonialium duo, et plura religiosorum et secularium monasteria, spoliis et incendio destruxerunt, inhumaniter religiosos et sacras deo dicatas virgins de claustris extrahentes, ministros ecclesie et sacerdotes, vasa sacra, vestes et sacramenta alia pertractantes. ${ }^{39}$ Therefore, it is obvious that the marriage and the political union were concluded by the two monarchs in order to achieve their political goals. Despite the Gediminids dynasty being finally accepted, there existed for a long period certain complications in the transfer of the throne, while the absence of a clearly regulated procedure for the transfer of power within the dynasty contributed to the elevation of individual groups within the nobility and their claims to influence the ruler, the desire of Gediminas to secure for his heirs the right to the throne, as well as to increase the authority of the Lithuanian ruler in the eyes of the European community. It should also be highlighted that while speaking about such an important alliance with the recognized Christian Polish king, the chronicler was quite neutral in characterizing Gediminas, acknowledging his royal status and ability to remain in contact with other Christian leaders of that time.

So although religion played an important role in the image of the rulers of the Grand Duchy of Lithuania, it was not of fundamental importance. Gediminas was not the only one to manipulate religion to achieve his political goals. This strategy began during the time of Mindaugas, continued during Vytenis' reign and found its apogee during the rule of Gediminas.

The desire of Gediminas to use religion for political purposes is reflected in the rhymed Latin composition written by the aforementioned Augustine Eucaedio:

Imperium Litaui regni Gedeminus habebat,

Pollicitus Christum accepturum sacraque nostra.

Ter conatus eum a vanis deducere Diuis Mutatum,

atque animo conuersum ad numina prisca:

Ter nihil efficient studium consumpsit inane,

Magnorum impensis operum fraudatus et auro. ${ }^{40}$

39 Petri de Dusburg Chronicon terrae Prussiae, p. 193.

40 Eucadius, A.: Aulaeum Dunadium, p. 411. 
It can be noted that the image of Gediminas underwent a peculiar transformation over time, depending on the specific socio-political conditions for the creation of a particular source or concept. However, it is obvious that the perception of him as a legitimate ruler depended not only on the traditions of the annals, but also on the political conditions for the creation of sources and the particular events described there.

We can conclude that even in the German narrative sources the image of the rulers of the Grand Duchy of Lithuania varied widely. One logical pattern, however, can be highlighted - the description of their politics and personality depended to a great extent on their religious politics. They all died as pagans, but even their attempt to acknowledge Christianity meant a great deal to the German chroniclers. After having been a Christian monarch for some period of time, the same ruler was described in different ways in comparison with his "pagan" period of reign. That is why they did not pay so much attention to the negative elements behind Mindaugas's baptism and coronation, and avoided mentioning his military strategy. Different situations are typical for the reigns of Vytenis and Gediminas. Whereas Vytenis was described as a cruel pagan, but a strong and noble enemy king, Gediminas is an entirely contradictory character, who makes some attempts to be baptized but refuses in the end. This fact, combined with his unknown origin, are most often the subjects of criticism. However, the two images of these rulers as pagan and Christian also acknowledge their legal royal status, as well as the existence of a strong enemy state - the Grand Duchy of Lithuania.

\section{Obraz pohanských a křestáanských vládců litevského velkoknížectví ze 2. poloviny 13. stol. a z 1. poloviny 14. století v německých kronikách}

Studie se soustřed’uje na obraz prvních vládců litevského velkoknížectví v německých kronikách. Jejím cílem je rekonstruovat obraz pohanských a křestanských panovníků formujícího se státního celku, zvýraznit vzájemné podobnosti a rozdíly a také charakterizovat legitimitu jejich panovnického postavení, již němečtí kronikáři hodnotili i z náboženského hlediska.

Náboženská prŕíslušnost vládce byla pro středověké kronikáře, pro kronikáře z řádu německých rytíř̉ zvláště, jednou z hlavních charakteristik. Tuto skutečnost jasně ilustruje příklad prvních litevských panovníků. Obraz vládce je tvořen nejen politikou, vojenskými událostmi nebo diplomatickými vztahy mezi dvěma státy, ale také jejich náboženskou příslušností - pohanstvím nebo křestanstvím. Článek se soustředuje na Mindaugase, Vytenise a Gedimina, tedy dominantní postavy z období, kdy byly kladeny základy litevského velkoknížectví.

Autorka zkoumá informace zprostředkované německými kronikáři ve 13. a 14. století: livonskou rýmovanou kronikou, Chronicon terrae Prussiae Petra z Dusburgu, Chronicon Livoniae Hermanna z Wartberge a Chronica nova Prutenica Wiganda z Marburgu. Zabývala se rovněž básní Aulaeum Dunaidum Augustina Eucaedia z poloviny16. století, která nabízí malebný obraz prvních litevských vládců. 
Rozbor pramenů ukázal, že němečtí kronikáři nabízejí rozdílné obrazy litevských velkoknížat, jejichž hodnocení značně záviselo na náboženské politice. Všichni zemřeli jako pohané, ale němečtí kronikáři oceňovali i jejich snahu s uznáním přistupovat ke křestanství. Poté, co se někdo z nich nechal pokřtít, byl popisován odlišným způsobem než v období své „pohanské“ vlády. Přesto je kronikáři považovali za právoplatné vládce bez ohledu na to, zda byli pohany či křestany. Za právoplatnou považovali i existenci silného nepřátelského státu - litevského velkoknížectví. 
